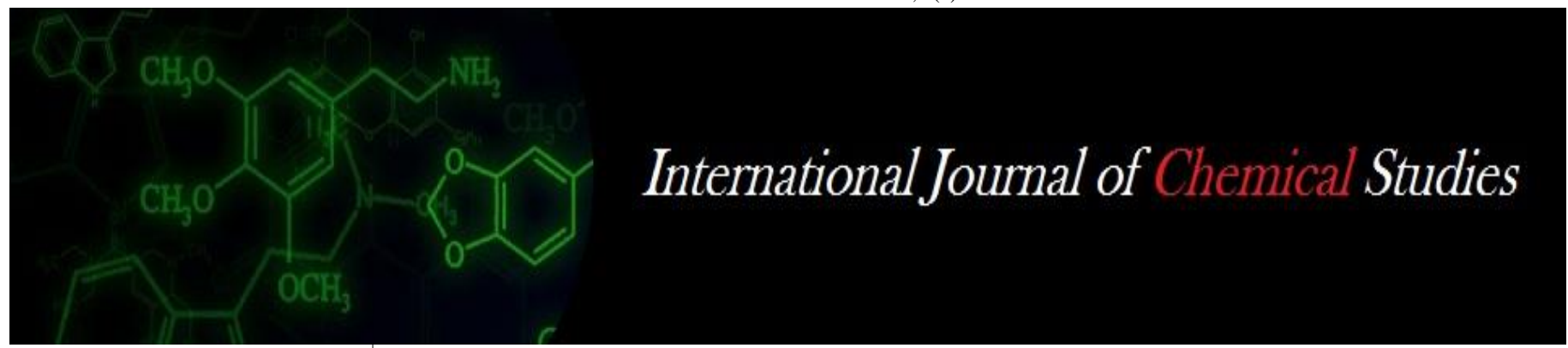

P-ISSN: 2349-8528

E-ISSN: 2321-4902

www.chemijournal.com

IJCS 2020; 8(4): 2056-2058

(C) 2020 IJCS

Received: 19-05-2020

Accepted: 21-06-2020

\section{Kaushal Kumar}

Department of Soil Conservation

and Water Management

C. S. Azad University of

Agricultures and Technology,

Kanpur, Uttar Pradesh, India

\section{Mayank Kumar}

Department of Soil Conservation and Water Management

C. S. Azad University of

Agricultures and Technology,

Kanpur, Uttar Pradesh, India
Corresponding Author:

\section{Kaushal Kumar}

Department of Soil Conservation

and Water Management

C. S. Azad University of

Agricultures and Technology,

Kanpur, Uttar Pradesh, India

\section{Studies on blackgram - Indian mustard cropping system under different rain water management practices in Jhararghat watershed}

\author{
Kaushal Kumar and Mayank Kumar
}

DOI: https://doi.org/10.22271/chemi.2020.v8.i4v.9931

\begin{abstract}
An experiment was conduct during two consecutive year of 2015-2016 and 2016-2017 at Hillocks and Valley Watershed of Jhararghat, Lalitpur, situated in catchments area of river Betawa. The soil of watershed area was sandy loam locally known as Rakar, having $\mathrm{pH} 8.1$, organic carbon $0.26 \%$, total nitrogen $0.02 \%$, available phosphorous $10.38 \mathrm{~kg} / \mathrm{ha}$ and available potassium $227.00 \mathrm{~kg} / \mathrm{ha}$ initially before starting of present experiment. The trail was conducted on farmers fields under blackgram-Indian mustard cropping system. There were four treatments comprised of conventional system, runoff recharge in stony dug wells, runoff harvesting at hill bottom in natural water impounding structure and runoff collection in constructed water storage structure. The treatments were evaluated on the basis of growth, yield attributes and yield of blackgram and growth yield traits and seed yield of Indian mustard. The blackgram variety Azad Urd-3 and Indian mustard cv. Varuna were sown with conservation agronomical practices.

The highest seed yield of blackgram by $9.06 \mathrm{q}$ /ha was reaped from runoff collection in constructed water storage structure of pilot area. The sowing of Indian mustard after blackgram in the same treatment $\left(\mathrm{T}_{4}\right)$ gave highest seed yield by $24.87 \mathrm{q} / \mathrm{ha}$. The growth and yield traits of both crops were concordant to the yields.
\end{abstract}

Keywords: Blackgram, mustard cropping, rain water management

\section{Introduction}

The rain water is the most valuable natural resource. It play a decisive role in agriculture production. Water needs of crops are greatly influenced by the factor, such as, evaporative, soil- water regime in the root zone, and the nature and the extent of plant foliage. A crop well supplied with water grow luxuriantly and makes more efficient use of available plant nutrients in soil and those applied through fertilizers. The soil moisture level influence the depth and volume of crop roots, and a well developed root system would be more effective in absorbing plant nutrients as compared to roots developed sparsely. Thus, it is highly imperative to maximize the utilization efficiency of irrigation and fertilizers, the two vital but limited and costly inputs in agricultural production.

The water management has still greater relevance in the food hill and valley areas in Bundelkhand region, most part of which remains seasonally dry in respect of crop production in spite of having high rainfall. Owing to the peculiar agro-climate and topographical conditions in these areas, the rain water management technique would naturally be quite different and specific as compared to those in the plains.

In hill and valley area of Bundelkhand (U.P.), generally mono cropping is in practice in the depressions. For changing the pattern of mono cropping in double cropping and to accelerate the productivity of blackgram and Indian mustard through double cropping system of blackgram-Indian mustard, the present study was conducted, which is subject matter of this manuscript.

\section{Materials and Methods}

The study was under taken during two consecutive years of 2015-16 and 2016-17 at Jharrarghat hillock watershed of Lalitpur district of Bundelkhand under rainfed situation. The operational area of watershed typically represent soil, climate and socio-economic condition of 
Bundelkhand Region. The soil of watershed was Rakhar, having $\mathrm{pH} 8.1$, organic carbon $0.26 \%$, total nitrogen $0.02 \%$, available phosphorus $10.38 \mathrm{~kg} / \mathrm{ha}$ and available potash 227.00 $\mathrm{kg} / \mathrm{ha}$, therefore, the fertility status was poor. The $\mathrm{pH}$ determined by Electrometric glass electrode method (Piper, 1950) [5], while organic carbon was determined by Colorimetric method (Datta, et al., 1962) ${ }^{[2]}$, total nitrogen was analyzed by Kjeldhal's method as discussed by piper (1950) [5]. The available phosphorus and potash were determined by Olsen's method (Olsen et al, 1954) ${ }^{[4]}$ and flame photometer method (Singh, 1971) ${ }^{[11]}$, respectively. The blackgram-Indian mustard cropping system was tested under four rain water management practices i.e., conventional system (C.S.), runoff recharge in stony dug wells (RRSW), runoff harvesting at hill bottom in natural water impounding structure (NWIS) and runoff collection in constructed water storage structure (CWSS). The blackgram was sown between 10-15 July on conserved moisture and harvested between 1015 October during both the experimental years. After harvesting of blackgram, the Indian mustard was seeded between 20-25 October and harvested between 20-25 February in both the years of study. The conservation agronomical practices were followed for raising of crops. The one protective irrigation was given to blackgram between pudding and pod filling stage. Three protective irrigations were given at 30, 60 and 90 days of seeding to Indian mustard. The analysis of individual year data for all characters of both the crops were done by standard method as developed by Fisher (1947) ${ }^{[3]}$. The pooling of data of different characters in blackgram and Indian mustard were done for two years by the standard method as suggested by Cochran and Cox, (1963) ${ }^{[1]}$.

\section{Results and Discussion}

The experimental findings as influenced by different treatments are discussed on the basis of pooled year's results, given in Table 1.

\section{(A) Blackgram \\ Growth characters}

The different rain water management practices did not uninfluenced significantly to plant stant after complete germination as well as at harvest. This was due to effective insitu moisture conservation in soil profile under all the tested treatments.

The maximum main shoot height was measured under runoff collection in constructed water storage structure, while shortest plant height was recorded under conventional system in pooled results of two years. The maximum main shoot height of blackgram available under $\mathrm{T}_{4}$ was due to increased moisture conservation in soil profile up to longer time. The maximum branches/plant was found in runoff collection in constructed water storage structure, while minimum, noted under conventional system, The more moisture conservation in T4 led to maximum branches/plant. The increase in plant height under T4 was also responsible for more branches.

\section{Yield contributing characters}

There has been considerable increase in number of pods per plant in T4 over other tested treatments. This explain that maximum pods/plant available in T4 was maximizing runoff and increasing in-situ moisture conservation in soil profile.
The variation in pods/plant under different treatments was also due to variation in number of branches/plant. There had been considerable improvement in seed weight/plant was found in runoff collection in constructed water storage structure(T4), while lowest was recorded under conventional system $\left(\mathrm{T}_{1}\right)$, This was due to variation in number of pods/plant. The weight of 100-seed was found higher in T4 and lowest noted in $\mathrm{T}_{2}$. The variation in 100-seed weight under different runoff harvesting system was due to variation in conserved moisture in soil profile.

\section{Seed yield (q/ha)}

Runoff collection in constructed water storage structure(T4) of rain water management practice gave highest grain yield( $9.06 \mathrm{q} / \mathrm{ha})$. which was significantly superior than the $\mathrm{T}_{1}$ $(6.31 \mathrm{q} / \mathrm{ha})$ and $\mathrm{T}_{2}(7.56 \mathrm{q} / \mathrm{ha})$ treatment but significantly at par with $\mathrm{T}_{3}(8.81 \mathrm{q} / \mathrm{ha})$. The increase in seed yield of blackgram may be attributed to the considerable increase in numbers of pots/plant, weight of seed/plant and weight of 100- seed. Similar results have also been reported by Singh (2009) ${ }^{[7]}$, Singh (2011) ${ }^{[8]}$, Singh (2013) ${ }^{[9]}$ and Singh (2015) [10].

\section{(B) Indian mustard}

\section{Growth characters}

There was no statistical variation among treatments in regards to plant stand after complete germination as well as maturity in pooled results of two years because all the tested runoff harvesting practices were proved effective in in-situ moisture conservation in soil profile. Rain water harvesting through runoff collection in constructed water storage structure was established supremacy in main shoot height over the other treatments. The shortest main shoot height of Indian mustard was measured in conventional system. The variation in the main shoot height was due to variation in in-situ moisture under different rain water management practices. The more moisture conservation in soil profile in T4 led to maximum branches/plant, The increase in branches/plant under T4 may be attributed to increase in plant height.

\section{Yield contributing characters}

The runoff collection in constructed water storage structure (T4) registered higher seed weight/plant over other tested rain water management measures. This was due to variation in growth parameter of Indian mustard under different rain water harvesting practices. Under different water harvesting methods, runoff collection in constructed water storage structure (T4) registered higher weight of 1000-seed. Conventional system produced lowest 1000 -seed weight. The variation in test weight under different rain water harvesting methods was due to variation in conserved moisture in soil profile.

\section{Seed yield (q/ha)}

The seed yield of Indian mustard recorded maximum under T4 method of moisture management $(24.87 \mathrm{q} / \mathrm{ha})$ in comparison to other tested treatments. The increase in seed yield may be attributed to the considerable increase weight of seeds/plant and weight of 1000-seed. Similar results have also been reported by Rathi et al. (1978) ${ }^{[6]}$, Singh (2009) ${ }^{[7]}$, Singh $(2011)^{[8]}$, Singh (2013) ${ }^{[9]}$ and Singh (2015) ${ }^{[10]}$. 
Table 1: Growth, yield traits and yield of blackgram raised under blackgram - Indian mustard

\begin{tabular}{|c|c|c|c|c|c|c|c|c|c|c|}
\hline \multirow[b]{2}{*}{ Treatment } & \multirow{2}{*}{\begin{tabular}{|c|} 
Plant stand \\
after complete \\
germination $/ \mathrm{ha}$
\end{tabular}} & \multirow{2}{*}{$\begin{array}{c}\text { Plant stand } \\
\text { at harvest/ha }\end{array}$} & \multirow{2}{*}{$\begin{array}{c}\text { Main root } \\
\text { height } \\
(\mathrm{cm})\end{array}$} & \multirow{2}{*}{$\begin{array}{c}\text { Branches } \\
\text { /Plant }\end{array}$} & \multirow{2}{*}{$\begin{array}{l}\text { Pods } \\
\text { /plant }\end{array}$} & \multirow{2}{*}{$\begin{array}{c}\text { Seed } \\
\text { weight } / \\
\text { plant }(g)\end{array}$} & \multirow{2}{*}{$\begin{array}{l}100-\text { seed } \\
\text { weight }(g)\end{array}$} & \multicolumn{3}{|c|}{ Seed yield (q/ha) } \\
\hline & & & & & & & & $\begin{array}{c}\text { I } \\
\text { year }\end{array}$ & $\begin{array}{c}\text { II } \\
\text { year }\end{array}$ & Pooled \\
\hline $\mathrm{T}_{1}$ - Conventional system (CS) & 374977 & 361853 & 42.10 & 3.31 & 24.18 & 3.42 & 3.56 & 6.25 & 6.37 & 6.31 \\
\hline $\begin{array}{l}\text { T2-Runoff recharge in stony dug wells } \\
\text { (RRSW) }\end{array}$ & 374988 & 361865 & 43.14 & 3.68 & 27.08 & 4.27 & 3.58 & 7.50 & 7.62 & 7.56 \\
\hline $\begin{array}{l}\text { T3-Runoff harvesting at hill bottom in } \\
\text { natural water impounding structure } \\
\text { (CWIS) }\end{array}$ & 374991 & 361868 & 44.12 & 3.93 & 32.12 & 6.52 & 3.64 & 8.75 & 8.87 & 8.81 \\
\hline $\begin{array}{l}\text { T4-Runoff collection in constructed } \\
\text { water storage structure (CWSS) }\end{array}$ & 374996 & 361873 & 44.31 & 4.18 & 33.31 & 7.05 & 3.68 & 9.00 & 9.12 & 9.06 \\
\hline S.E. $\left(\mathrm{m}^{ \pm}\right)$ & 124.91 & 109.96 & 0.29 & 0.04 & 0.37 & 0.10 & 0.04 & 0.23 & 0.24 & 0.16 \\
\hline C.D. $5 \%$ & N.S. & N.S. & 0.82 & 0.11 & 1.05 & 0.28 & N.S. & 0.67 & 0.70 & 0.45 \\
\hline
\end{tabular}

Table 2: Growth, yield traits and yield of Indian mustard raised after blackgram under blackgram- Indian mustard cropping system

\begin{tabular}{|c|c|c|c|c|c|c|c|c|c|}
\hline \multirow[b]{2}{*}{ Treatment } & \multirow{2}{*}{\begin{tabular}{|c|} 
Initial \\
plant \\
stand (ha)
\end{tabular}} & \multirow{2}{*}{$\begin{array}{c}\text { Plant stand } \\
\text { at harvest/ha }\end{array}$} & \multirow{2}{*}{$\begin{array}{l}\text { Main shoot } \\
\text { height }(\mathbf{c m})\end{array}$} & \multirow{2}{*}{$\begin{array}{c}\text { Branches } \\
\text { /plant }\end{array}$} & \multirow{2}{*}{$\begin{array}{c}\text { Seed } \\
\text { weight } / \\
\text { plant }(g)\end{array}$} & \multirow{2}{*}{$\begin{array}{c}1000- \\
\text { seed } \\
\text { weight }(\mathrm{g})\end{array}$} & \multicolumn{3}{|c|}{ Seed yield (q/ha) } \\
\hline & & & & & & & I year & II year & Pooled \\
\hline $\mathrm{T}_{1}$ - Conventional system $(\mathrm{CS})$ & 79890 & 71890 & 164.56 & 47.30 & 27.08 & 4.68 & 13.37 & 14.00 & 13.93 \\
\hline T2-Runoff recharge in stony dug wells (RRSW) & 79903 & 71913 & 167.08 & 47.82 & 37.10 & 4.81 & 18.75 & 19.12 & 18.93 \\
\hline $\begin{array}{l}\text { T3-Runoff harvesting at hill bottom in natural water } \\
\text { impounding structure (CWIS) }\end{array}$ & 79918 & 71938 & 168.56 & 50.80 & 42.32 & 4.90 & 23.00 & 23.00 & 23.00 \\
\hline $\begin{array}{c}\text { T4-Runoff collection in constructed water storage } \\
\text { structure (CWSS) }\end{array}$ & 79937 & 71967 & 169.06 & 52.05 & 46.82 & 4.94 & 24.75 & 25.00 & 24.87 \\
\hline S.E. $\left(\mathrm{m}^{ \pm}\right)$ & 110.63 & 40.11 & 0.65 & 0.44 & 0.66 & 0.04 & 0.63 & 0.58 & 0.43 \\
\hline C.D. $5 \%$ & N.S. & N.S. & 1.85 & 1.25 & 1.88 & 0.11 & 1.85 & 1.70 & 1.22 \\
\hline
\end{tabular}

\section{Conclusion}

The farm families residing in dry farmed area of Uttar Pradesh may be suggested for adoption of double cropping of blackgram-Indian mustard instead of mono-cropping of monoculture.

\section{References}

1. Cochraran WG, Cox GM. Experimental Design. Asia publishing house Bombay 1963, 293-305

2. Datta NP, Khera MS, Sani TR. A rapid colorimeter procedure for determination of organic carbon in soil. Journal of Indian Society of soil Science. 1962; 10:67-74

3. Fisher RA. The design of experiments. oliver and Bayd, Edinburg $4^{\text {th }}$ ed, 1947.

4. Olsen SR, Cole CV, Watanable FS, Dean LA. Estimation of available phosphorus in soil by extraction with sodium bicarbonate, U.S.D.A. Circ. 939 (Washington), 1954, 19.

5. Piper CS. Soil and plant Analysis. University Adelaide Aust, 1950.

6. Rathi KS, Singh RA, Singh VP. Agronomic practices in mustard Varuna. Indian Farming. 1978; 28(4):27-29.

7. Singh RA. Rain water management with three tier system in rainfed affected area of Bundelkhand, Abstract (In), Conference on Food and Environmental Security Through Resource Conservation in Central India., organized by CSWCRT, Institute, on 16-18 September at Agra, 2009.

8. Singh RA. Rain water management with three tier system in ravines affected area of Bundelkhand. Indian Journal of Soil Conservation. 2011; 39(1):14-19.

9. Singh RA. Crop production through diversion system of rain water in hillocks area of Bundelkhand, U. P. Abstract (In), 24 $4^{\text {th }}$ National Conference on Sustainable Farming system and Bio-industrial Watershed Mangement for Food and Enhancing Income of Farming Community, organized by SCS of India, New Delhi on 16-17 April at Lucknow, 2013.
10. Singh RA. Crop production through diversion system of rain water management in hillocks area of Bundelkhand. Indian Journal of Soil Conservation. 2015; 43(2):166169.

11. Singh TA. A laboratory manual for soil fertility and fertilizers. U.P. Agri. Univ : (Pantnagar), 1971, 71-74 